\title{
Household electricity consumers' incentive to choose dynamic pricing under different taxation schemes
}

Electricity consumers' incentive to choose dynamic pricing

Katz, Jonas; Kitzing, Lena; Schröder, Sascha Thorsten; Møller Andersen, Frits; Morthorst, Poul Erik; Stryg, Morten

Published in:

Wiley Interdisciplinary Reviews: Energy and Environment

Link to article, DOI:

10.1002/wene.270

Publication date:

2018

Document Version

Peer reviewed version

Link back to DTU Orbit

Citation (APA):

Katz, J., Kitzing, L., Schröder, S. T., Møller Andersen, F., Morthorst, P. E., \& Stryg, M. (2018). Household electricity consumers' incentive to choose dynamic pricing under different taxation schemes: Electricity consumers' incentive to choose dynamic pricing. Wiley Interdisciplinary Reviews: Energy and Environment, 7(1), [e270]. https://doi.org/10.1002/wene.270

\section{General rights}

Copyright and moral rights for the publications made accessible in the public portal are retained by the authors and/or other copyright owners and it is a condition of accessing publications that users recognise and abide by the legal requirements associated with these rights.

- Users may download and print one copy of any publication from the public portal for the purpose of private study or research.

- You may not further distribute the material or use it for any profit-making activity or commercial gain

- You may freely distribute the URL identifying the publication in the public portal 


\title{
Household electricity consumers' incentive to choose dynamic pricing under different taxation schemes
}

\author{
Jonas Katz ${ }^{* 1}$, Lena Kitzing ${ }^{1}$, Sascha T. Schröder ${ }^{1}$, Frits Møller Andersen ${ }^{1}$, Poul Erik Morthorst ${ }^{1}$, \\ and Morten Stryg ${ }^{2}$ \\ ${ }^{1}$ Department of Management Engineering, Technical University of Denmark, Kgs. Lyngby, Denmark \\ ${ }^{2}$ Dansk Energi, Frederiksberg, Denmark
}

June 8, 2017

\section{Article Type:}

Focus Article

\begin{abstract}
Dynamic pricing of retail electricity, as opposed to the widely applied average pricing, has often been proposed to enhance economic efficiency through demand response. The development of variable production from renewable energies and expectations about the installation of heat pumps and electric vehicles have now reinforced interest in flexible demand and dynamic pricing. With a roll-out of smart metering one important technical hurdle is going to be cleared, and dynamic retail pricing may soon become an eligible option for many households. We quantify the potential incentives to adopt new pricing schemes using exemplary Danish data. Until now, limited activity of household consumers on retail markets indicates that switching supplier or contract is perceived costly. We apply the concept of switching costs to explain this hesitant behaviour, and use it to estimate a threshold level based on recent observations in the Danish market. We calculate potential savings from dynamic pricing and show how the choice of electricity taxation technique may hamper or enhance potential benefits. In the light of switching costs, our results suggest that the combination of smart meter roll-out and dynamic pricing offerings might be insufficient to convince the majority of households to switch contracts and become active in response to prices, unless they hold a substantial flexibility potential. Dynamic taxation, even if applied to parts of the levies, could contribute significantly to induce flexible consumption.
\end{abstract}

\footnotetext{
*Correspondence to: jokat@dtu.dk
} 


\section{INTRODUCTION}

Dynamic pricing of retail electricity has become a recurring item on the energy policy agenda. If introduced instead of the ubiquitous average pricing, it generates economic efficiency gains - assuming retail demand is price responsive. ${ }^{1}$ So far, however, technical and administrative requirements as well as uncertainty about potential gains have prevented implementation in many markets. Large-scale development of variable production from renewable energies in Denmark has now reestablished an interest in flexible demand and dynamic pricing. ${ }^{2,3}$ As the effectiveness of new pricing schemes depends largely on individual decisions of households, this paper explores implications of dynamic electricity pricing in Denmark from a household consumer perspective. While theoretical gains are mostly undisputed, ${ }^{4,5}$ it remains an open question whether electricity retail customers find it attractive to adopt dynamic pricing schemes and responsive behaviour. ${ }^{6,7}$

A certain flexibility potential is assumed to be present also in Danish households, ${ }^{8,9}$ and consumers are continuously equipped with smart meters. ${ }^{10}$ Some regulatory issues regarding data access and settlement have thus far hindered the development of dynamic price products. ${ }^{11}$ With the implementation of a data hub and new retail market rules, though, all consumers in a foreseeable future should have the possibility to switch to an hourly-varying price contract, both technically and in terms of access to competitive products. This leaves us with the question of consumers' potential financial benefits, providing an incentive to switch to dynamic rates and become responsive to varying prices.

To date the Danish retail price is dominated by fixed per-unit elements: ${ }^{12}$ payments for grid use, fiscal levies and the para-fiscal public-service-obligation (PSO) levy that mainly finances renewable energy support (see Figure 1). In effect, the payments for all levies are directly proportionate to the volume of consumption. Even with dynamic pricing of the purely market related part, relative variability becomes almost invisible to the consumer. Analyses of retail electricity prices in Denmark thus must consider taxes. In order to sustain the relative variations in the underlying market price and increase the incentive for demand response under dynamic pricing, a changed dynamic approach to levies and 
taxes could become relevant. ${ }^{13,14} \mathrm{~A}$ few studies already assess the possibility of dynamically linking the para-fiscal levy that finances renewable support in Germany to spot market prices. ${ }^{15,16}$ In Denmark dynamic taxes and levies have gained some attention in the debate as well. ${ }^{17,18}$ But while some new dynamic electricity tax structures based on market indicators, such as the amount of wind power in the system, have been assessed, ${ }^{19}$ we did not find any work exploring the details of value-based or ad-valorem taxation based on the underlying electricity price.



Figure 1: Danish household electricity price (4000 kWh/year) in $2013^{20}$

The overall aim of our paper is to provide an indication of whether dynamic pricing could be competitive as a product on the Danish retail electricity market taking into account the possibility of consumers to respond to hourly prices in order to generate benefits. Therefore we estimate potential benefits of consumers switching to a dynamic pricing scheme under different assumptions of their ability to respond to prices. To gain insight into the distribution of benefits among households we use disaggregated load profiles for different types of homes. In our evaluation we take into account all elements of the retail price including taxation. We also determine the gains of converting fixed perunit adders to the electricity price into dynamic elements and evaluate the impact on the attractiveness of dynamic rates. This is done for both the fiscal levies (dynamic tax) and for the public-service-obligation levy (dynamic PSO).

While any demand response optimisation would result in financial benefits, it is un- 
clear what level of benefits would actually be required to trigger adoption of dynamic pricing and responsive behaviour. We do have information, though, about the behaviour of household consumers on the Danish retail market. Based on this information we propose threshold levels and evaluate the attractiveness of dynamic pricing schemes as a viable option to customers under retail competition.

\section{Determining the attractiveness of dynamic pricing}

\section{Disaggregated hourly consumption data set}

To account for heterogeneity of consumers we evaluate benefits on a disaggregated basis. Actual hourly metering data has been acquired on household or sub-station level for Danish consumers in the period of 2007-2012. Information on electric heating is available as well. Measurements are obtained by various network companies that report to the Danish Energy Association (Dansk Energi) and the Danish transmission system operator (Energinet.dk) on a regular basis. Information on the used data set is shown in Table 1. It covers a total of 652 meters, many on a sub-station level. On average a metering point covers around 14 individual households. In total the data set covers 9215 household customers with an average consumption of $3941 \mathrm{kWh}$ per year. To maintain comparability between consumers the metering data for a connection point is scaled down according to the number of households connected where necessary. Therefore the load-shift potential of individual households in some cases is estimated by using the shape of the respective sub-station profile.

Table 1: Used hourly consumption data set

\begin{tabular}{|c|c|c|c|c|c|c|}
\hline & \multirow{2}{*}{$\begin{array}{c}\text { Meters } \\
\text { total }\end{array}$} & \multicolumn{2}{|c|}{ Consumers } & \multicolumn{3}{|c|}{ Consumption } \\
\hline & & total & $\begin{array}{l}\text { per } \\
\text { meter }\end{array}$ & $\begin{array}{l}\text { average } \\
{[\mathrm{kWh} / \mathrm{y}]}\end{array}$ & $\begin{array}{l}\text { share in } \\
\text { used data }\end{array}$ & $\begin{array}{c}\text { share in } \\
2013\end{array}$ \\
\hline Apartments & 86 & 5,691 & 66.2 & 3,464 & $11.6 \%$ & $24.4 \%$ \\
\hline Semi-/detached houses & 566 & 3,524 & 6.2 & 4,013 & $88.4 \%$ & $75.6 \%$ \\
\hline without electric heating & 557 & 3,057 & 5.5 & 3,999 & $86.7 \%$ & $62.5 \%$ \\
\hline with electric heating & 9 & 467 & 51.9 & 4,858 & $1.7 \%$ & $13.1 \%$ \\
\hline Total & 652 & 9,215 & 14.1 & 3,941 & $100.0 \%$ & $100.0 \%$ \\
\hline
\end{tabular}


In Denmark residential consumption of electricity accounts for about 30\% of total electricity consumption, the major share consumed in detached or semi-detached homes. ${ }^{21}$ Most commonly no electric heating is installed. The shares of consumption per category in the used data are shown in Table 1 together with the actual shares in Denmark of 2013. Due to its composition and the scaling of some profiles to household level, the used data set is not fully representative of Danish residential consumption. In terms of total consumers, apartments are overrepresented, but as we only use one profile per meter, this category will eventually be slightly underrepresented in the final average results. The results per category, however, are unaffected, and the data still provides a good basis to estimate household-level effects of dynamic pricing.

\section{Benefits from dynamic pricing}

The incentive to adopt a new contract is approximated by simulating potential response activities and resulting savings on individual customers' electricity bills. Based on the actual metering data the total annual electricity bill of a household is determined, at first, by applying a traditional flat price per $\mathrm{kWh}$ that is adjusted every quarter of a year. This is then compared to hourly pricing. All end-user prices include relevant levies and taxes within the analysed time period and have been deflated to the level of 2012, the last year in the used data set. In addition to applying the current per-unit taxation scheme we also derive results adding dynamic, ad-valorem levies for both the fiscal and para-fiscal elements. In all cases these are defined as a percentage such that they result in the same annual revenues if consumers would not respond to prices.

For simplicity we use a stylised demand response model rather than estimates of price-elasticity or models of specific appliances. Load shift occurs to the lowest priced hours within predefined time slices. We restrict the shifting by assuming that consumers will not reduce their demand below the lowest hourly consumption measured during one full year. Moreover, we assume that the measured peak during one year represents the 
connected load of household appliances reduced by a coincidence factor $(\mathrm{CF})$ :

$$
\mathrm{CF}=\frac{\text { Peak load }}{\text { Total connected load }}
$$

Applying the factor to the peak load therefore gives us a theoretical maximum load per household. A common approximation of the coincidence factor for different numbers $n$ of connected loads is given by: ${ }^{22}$

$$
\mathrm{CF}=0.5\left(1+\frac{5}{2 n+3}\right)
$$

For large numbers of connected loads of around 250 this approximation approaches 0.5. We use this number for the apartment category. Although a single apartment might not have 250 loads connected, we want to account for that the used profiles actually cover larger blocks of apartments. In this way, when scaled down to a single apartment, we avoid underestimating the individual peak loads. For detached homes we use a slightly higher factor of 0.55 assuming that fewer electrical loads are covered by the profiles (using equation (2) the value corresponds to around 23 loads). For customers with electric heating we use a factor of $0.8^{23}$.

In mathematical terms our approach is equivalent to the following simple optimisation problem:

$$
\begin{array}{rlrl}
\min _{d \geq 0} & \sum_{t=1}^{T} d_{t} P_{t} & & \\
\text { s.t. } & d_{t} \geq \min _{t} D_{t}^{0} & \forall t \in T \\
& \frac{1}{\mathrm{CF}} \max _{t} D_{t}^{0} \geq d_{t} & \forall t \in T \\
\sum_{s=t}^{t+L-1} d_{s} & =\sum_{s=t}^{t+L-1} D_{s}^{0} & \forall\left\{t \in T \mid t=L(m-1)+1, m \in \mathbb{Z}^{+}\right\}
\end{array}
$$

We minimise costs given by multiplying the chosen demand level $d$ with the end user price $P$. The original metered consumption $D_{0}$ determines upper and lower bounds of $d$ applying the principles described above. The last constraint ensures that load is shifted and not just curtailed: within given time windows of length $L$ the sum of load after shift- 
ing $(d)$ needs to be equal to the sum of loads in the original profile $\left(D_{0}\right)$. We use windows of $3,6,12,24$ and 168 hours to represent the potential load shift horizons. These time slices cover the most important short-term patterns in hourly electricity prices. Moreover, it may be assumed that the load-shift potential of a household customer is somewhat limited and would not exceed the maximum period of one whole week (i.e. 168 hours).

In order to estimate a savings potential we apply rather optimistic constraints. Deriving results for this kind of best-case scenario helps us to determine, whether a sufficient economic incentive to adopt dynamic pricing can be expected, and consequently, whether such options can be attractive on a liberalised retail market.

\section{Threshold benefit levels of consumers}

Several studies have investigated benefits of demand response under dynamic pricing. ${ }^{24-26}$ A number of these also estimate financial impacts on household consumers. ${ }^{27}$ We argue, though, that consumer benefits of demand response should not be seen in isolation. Rather, they should be analysed with consumers' adoption decisions in mind. Making consumers actively participate will become one of the critical issues in the further development of demand response under retail competition. ${ }^{28,29}$ We therefore analyse our results in the context of observed behaviour in the liberalised Danish retail market.

Switching rates of 3-7\% indicate that consumers in Denmark are mostly comfortable with their suppliers and the prices they offer. ${ }^{30,31}$ For the largest share of consumers this means they are buying electricity at traditional flat rate conditions. ${ }^{32}$ Potential savings of switching from the traditional rate to competitive offers can be observed to be around 5$10 \%$ - on average not more than $€ 50$ per year; for many customers this does not provide a sufficient incentive. An offer that in addition would ask for the consumer to change behaviour as a precondition to obtain savings (as in the case of load-shifting) would likely require larger savings. For example, research in Germany has shown that consumers on average expected savings of $€ 54$ per year (more than $5 \%$ of their total bill) from giving access to automatic control of their fridges alone. ${ }^{33}$ A Swedish survey resulted in even higher figures. ${ }^{34}$ 
With homogeneous goods like electricity one should expect that small price differences would be sufficient to induce switching. In practice, we can see that this is not the case. For households in particular, factors beyond the financial incentive do play a role as previous research has found. ${ }^{35}$ A Dutch survey, for example, has shown that autonomy, privacy and comfort are highly valued and that households may be very reluctant towards participating if these factors are compromised. ${ }^{36}$ The findings seem to be supported by a Swiss experiment characterising only $20 \%$ of a sample of household consumers as "price sensitive", whereas the remaining share focussed more on rate stability, home automation and security. ${ }^{37}$ Furthermore, in a German study $69 \%$ of respondents preferred a fixed rate to dynamic pricing as well. ${ }^{38}$

The observed switching behaviour as well as the above findings regarding household consumer preferences suggest that potential benefits would need to outweigh a range of intangible costs associated with switching to another supplier or pricing scheme. ${ }^{39}$ If we could determine the cost of switching and compare it with the benefits of a dynamic rate, then we would have an estimate of the required level of benefits from a consumer point of view in order to switch to such new schemes. This is not easily measured, but fortunately a simplified method to determine the cost of switching has already been developed. ${ }^{40}$ It simply uses market shares and price differences observed for a homogeneous product in the market, and has been applied previously, for example, in the context of electricity, ${ }^{41}$ internet providers ${ }^{42}$ or the airline industry. ${ }^{43}$

A dominant market position with deviating prices in this framework is explained by switching costs. Switching cost $S_{A B}$ of supplier A's customers switching to supplier B with respective market shares $M$ and prices $p$ is defined as:

$$
S_{A B}=p_{A}-\frac{M_{B} p_{B}}{M_{A}+M_{B}}
$$

This expression results from the assumption that the observed prices of $A$ and $B$ are chosen such that it is unattractive for any of the two suppliers - costs of switching taken into account - to offer their product to the other supplier's customers at sufficiently low prices to switch. Supplier B would have to offer a price of $p_{A}$ minus $S_{A B}$ in order to 
convince A's customers to switch. Switching costs may then be determined by observing that the actual revenue of supplier $\mathrm{B}, p_{B} M_{B}$, has to be more or at least equally attractive to the revenue resulting from getting supplier A's customers to switch, which is: $\left(p_{A}-\right.$ $\left.S_{A B}\right)\left(M_{A}+M_{B}\right)$. Setting these two expressions equal and rearranging results in equation (4).

The data on market shares of suppliers in Denmark that is required to determine the above switching cost is not readily available. We therefore use the Herfindahl-Hirschman Index (HHI) for market concentration regularly published by the Danish transmission system operator. ${ }^{44}$ The index is defined as:

$$
\mathrm{HHI}=\sum_{i=1}^{N} M_{i}^{2}
$$

As the number of market participants is made public, we can approximate the market share of the largest supplier $M_{1}$ assuming that the remaining share is divided equally amongst all other suppliers:

$$
\mathrm{HHI}=M_{1}^{2}+(N-1)\left(\frac{1-M_{1}}{N-1}\right)^{2}
$$

While 70 suppliers are active in Denmark in total, only a part of them supply customers in the whole country. For the calculation of market shares we therefore define the market to consist of 44 suppliers, which is the maximum number active in any distribution area. As traditionally consumers have been supplied by their local utility company, we take into account the concentration index within local distribution areas, where the weighted average $\mathrm{HHI}$ value lies at 0.7 , resulting in an average $84 \%$ market share of the largest supplier. Being with the largest supplier does not necessarily mean that customers have not been active on the market by comparing prices or choosing new contracts. This could be taken into account by using the share of consumers on a traditional fixed price product as the incumbent market share instead of the one derived from the HHI. This alternative value is around $55 \% .^{32}$

Switching costs are estimated by applying equation (4). We use the above incumbent 
market shares as $M_{A}$ and the combined share of all competitors as $M_{B}$. As the incumbent price we use average supply costs based on a traditional flat rate price, whereas for the competitors we use the most attractive offers in the retail market: products with prices fixed at the most for 6 months ahead. Resulting switching cost estimates are given in Table 2. We use these benchmark levels below to evaluate estimated savings generated by a switch to dynamic pricing under different tax regimes.

Table 2: Switching cost estimates

\begin{tabular}{lrr}
\hline & $\begin{array}{c}\text { Incumbent } \\
\text { share [-] }\end{array}$ & $\begin{array}{c}\text { Switching } \\
\text { cost [€] }\end{array}$ \\
\hline Local HHI & $84 \%$ & 114 \\
Fixed price share & $55 \%$ & 78 \\
\hline
\end{tabular}

\section{Results}

\section{Consumer benefits of dynamic pricing under different taxation schemes}

Figure 2 shows resulting costs subdivided by price element. The top panel shows results in the reference case of flat pricing. The other two panels show results for dynamic pricing with and without a dynamic tax under different assumptions about the load-shifting time window. As expected, larger windows reduce the supply cost for customers under dynamic pricing, and the effect becomes even more pronounced with a dynamic tax replacing the unit tax. Individual costs span a wide range from as low as $€ 100$ and up to far above $€ 2000$ per year. To provide an indication of the distribution of costs among households and consumer categories we use boxplots. In these, 50\% of the results lie within the boxes, and the bars are set to cover $95 \%$ of the results. The means are indicated by different shapes per category and deviate from the median line, due to asymmetric distributions in some of the results.

The average benefits of switching to another pricing scheme are summarised in Table 3 for different customer categories and in total. Horizontally the table shows potential benefits from shifting load within the analysed time windows. The first section represents a switch from flat to dynamic pricing maintaining per-unit levies on electricity. The 


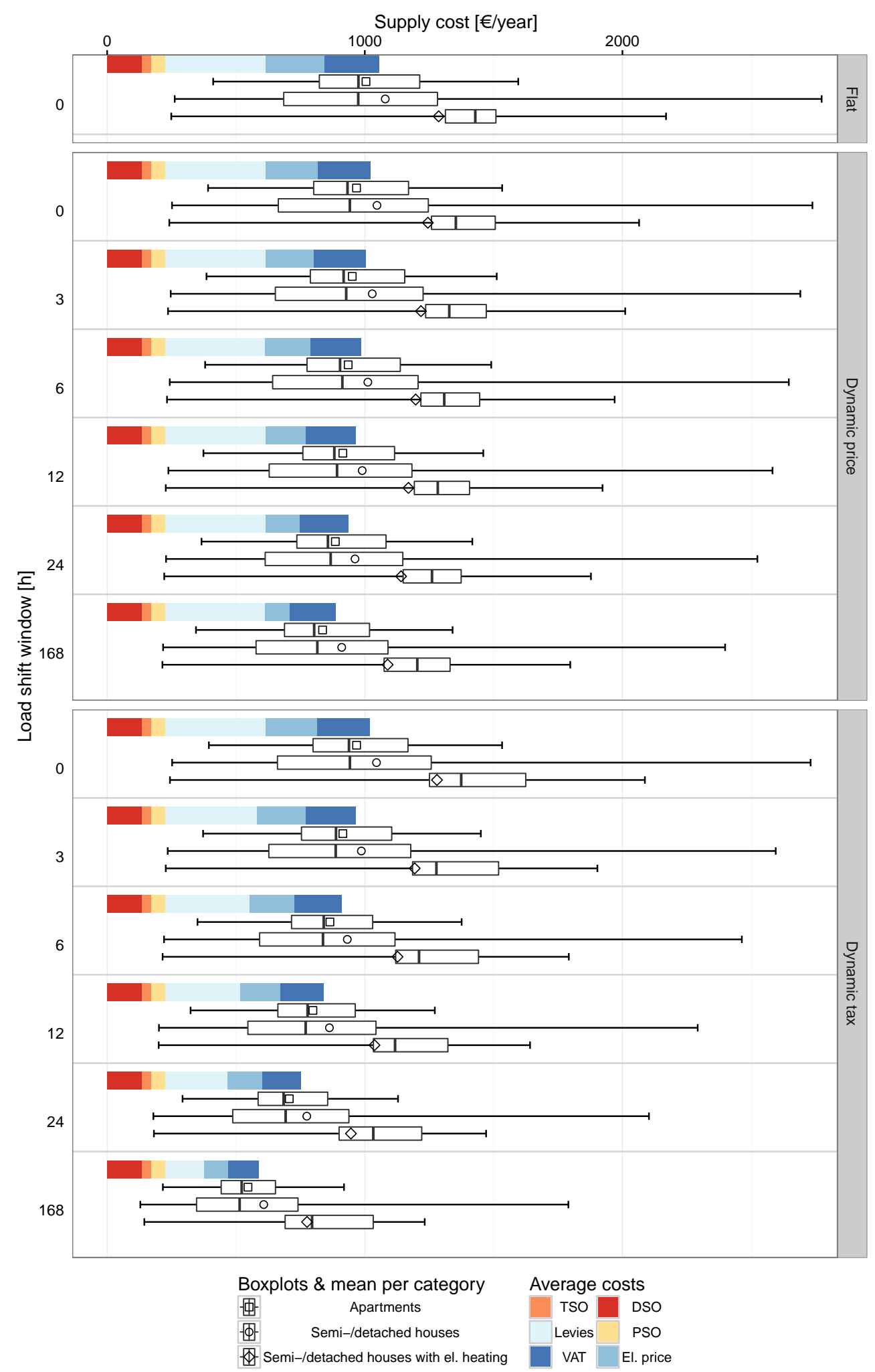

Figure 2: Supply cost results of load shift simulations under different pricing and tax regimes 
Table 3: Average benefits of switching to dynamic pricing under different taxation schemes by load shift window

\begin{tabular}{|c|c|c|c|c|c|c|}
\hline & \multicolumn{6}{|c|}{ Load shift horizon } \\
\hline & $\begin{array}{c}\text { no resp. } \\
{[€ / y]}\end{array}$ & $\begin{array}{c}3 \text { hours } \\
{[€ / y]}\end{array}$ & $\begin{array}{c}6 \text { hours } \\
{[€ / y]}\end{array}$ & $\begin{array}{c}12 \text { hours } \\
{[€ / y]}\end{array}$ & $\begin{array}{c}24 \text { hours } \\
{[€ / y]}\end{array}$ & $\begin{array}{c}168 \text { hours } \\
{[€ / y]}\end{array}$ \\
\hline \multicolumn{7}{|l|}{ Dynamic price } \\
\hline Apartments & 36.8 & 53.3 & 69.0 & 89.8 & 118.9 & 168.5 \\
\hline Semi-/detached homes & 32.4 & 51.0 & 68.2 & 90.3 & 118.3 & 169.9 \\
\hline without electric heating & 32.1 & 50.5 & 67.6 & 89.5 & 117.4 & 169.0 \\
\hline with electric heating & 41.9 & 68.7 & 89.4 & 117.3 & 145.8 & 198.1 \\
\hline All categories & 34.1 & 51.9 & 68.5 & 90.1 & 118.5 & 169.4 \\
\hline net load-shift benefit & - & 17.8 & 34.5 & 56.1 & 84.5 & 135.3 \\
\hline \multicolumn{7}{|l|}{ Dynamic price and PSO } \\
\hline Apartments & 36.9 & 58.8 & 79.5 & 106.6 & 144.4 & 210.0 \\
\hline Semi-/detached homes & 32.4 & 57.1 & 79.9 & 109.0 & 145.6 & 215.0 \\
\hline without electric heating & 32.4 & 56.7 & 79.4 & 108.3 & 144.8 & 214.1 \\
\hline with electric heating & 32.7 & 68.6 & 96.1 & 133.0 & 170.8 & 242.4 \\
\hline All categories & 34.1 & 57.8 & 79.7 & 108.1 & 145.2 & 213.1 \\
\hline net load-shift benefit & - & 23.7 & 45.7 & 74.0 & 111.1 & 179.0 \\
\hline \multicolumn{7}{|l|}{ Dynamic price and tax } \\
\hline Apartments & 36.5 & 89.8 & 140.0 & 206.0 & 297.7 & 458.1 \\
\hline Semi-/detached homes & 33.2 & 92.8 & 147.7 & 217.8 & 305.7 & 472.9 \\
\hline without electric heating & 34.0 & 92.8 & 147.3 & 216.7 & 304.6 & 471.6 \\
\hline with electric heating & 6.6 & 93.0 & 159.7 & 249.2 & 340.6 & 510.8 \\
\hline All categories & 34.5 & 91.6 & 144.7 & 213.3 & 302.7 & 467.2 \\
\hline net load-shift benefit & - & 57.2 & 110.3 & 178.8 & 268.2 & 432.8 \\
\hline \multicolumn{7}{|l|}{ Dynamic price, PSO and tax } \\
\hline Apartments & 36.6 & 95.3 & 150.4 & 222.8 & 323.2 & 499.7 \\
\hline Semi-/detached homes & 33.1 & 98.8 & 159.3 & 236.4 & 333.0 & 517.9 \\
\hline without electric heating & 34.3 & 99.0 & 159.1 & 235.5 & 332.0 & 516.8 \\
\hline with electric heating & -2.6 & 92.9 & 166.5 & 264.9 & 365.6 & 554.0 \\
\hline All categories & 34.5 & 97.5 & 155.9 & 231.3 & 329.3 & 511.0 \\
\hline net load-shift benefit & - & 63.0 & 121.5 & 196.8 & 294.8 & 476.6 \\
\hline
\end{tabular}

remaining sections of Table 3 show the effects of introducing dynamic PSO payments and taxes. There is an advantage to be gained by switching from the default product to an hourly-price product even without load shifting (column 'no resp.'). This has to be kept in mind when looking into the potential of demand response actions. Although significant benefits may be achieved in total, some of those will have to be attributed to the mere effect of hourly pricing that for some part covers the implicit insurance premium in a fixed price. As competition increases one may expect this gap to become smaller, though. Therefore the last line in each section of Table 3 shows the net load-shift benefit 
that would be achievable even if the average level of flat and dynamic pricing would be exactly the same.

It does not seem to play a large role in the average benefits whether the consumers live in apartments or detached homes. Additional consumption from electric heating is an advantage when it comes to load shifting. What cannot be seen from the presented average figures is that the benefits are not equal in all years of the data set and electricity bills may become more volatile with hourly pricing schemes. Electric heating customers are particularly vulnerable to high prices during the heating season. Therefore dynamic pricing holds a certain risk for these customers. If the dynamics are further increased through taxation this may have adverse effects if customers with electric heating do not react to prices properly.

Switching from static unit taxation to dynamic ad-valorem taxation would support the incentive for demand response. Even when correcting for savings that result from the mere switch between a flat and a dynamic electricity price, demand response generates significant savings under dynamic taxation. In all of the simulated cases the load-shift benefits under dynamic taxation are more than three times the amount achieved under dynamic pricing with traditional taxation. Admittedly, a dynamic tax would be a rather substantial intervention. Therefore we also analysed the option of a dynamic PSO payment, both as a separate instrument and in combination with a dynamic tax (see Table 3). Similar effects can be achieved by a dynamic PSO, though to a lesser degree. Benefits would increase by more than $30 \%$ as compared to a fixed PSO payment under dynamic pricing. Combining dynamic tax and PSO would yield the maximum incentive for loadshifting with savings around 3.5 times those of dynamic pricing with fixed levies.

\section{Attractiveness of pricing schemes}

Considering the total average electricity bill of more than $€ 1000$ under flat pricing (see Figure 2), demand response alone (after switching from a flat to a dynamic price) generates savings in a range of $2-10 \%$ of total costs. This is comparable to price differences we have seen under retail competition in the past, ${ }^{32}$ but may still seem somewhat lim- 
ited considering the rather optimistic assumptions of our demand response simulation. Dynamic taxation could increase results by a factor three, and such savings should make it far more likely to motivate customers to switch contracts if we use today's switching behaviour as an indicator. We will have to return to our switching cost benchmarks, however, to further conclude whether such savings are sufficiently attractive or not.

Figure 3 shows distributions of cost savings under dynamic pricing for unit and dynamic tax regimes subject to optimal load shifting under the given constraints. The mean levels for the three different residential consumer categories are indicated by vertical lines of the same colour as the distribution. As benchmarks we show the two levels of switching costs from Table 2 as grey vertical bars. Moreover, we indicate gains that may be obtained by a simple switch of supplier under current retail market conditions by a third bar. A first thing to note is how differently an hourly pricing regime may affect customers. Due to the different individual profiles some households are only able to achieve savings in the low end. It may even be the case that certain customers lose on dynamic pricing. Another small group of customers will profit substantially from variable pricing regimes.

The light blue distributions show savings under the present unit taxation. Without any response, the level will lie at or around the observed savings from switching supplier in the market. Although dynamic pricing provides benefits even without becoming flexible, it is unlikely that residential consumers would choose it with similarly attractive, but more stable, options at hand. Adding flexibility, switching may become attractive; the lower switching cost benchmark is exceeded at windows of 12 hours for all three consumer categories. The higher switching cost level is exceeded with full flexibility within 24 hours. For most consumers such levels of flexibility can only be achieved for parts of their consumption, so the simulated savings will be difficult to achieve in practice. With dynamic taxation (dark blue lines and distributions) the lower switching cost benchmark will be exceeded already by being flexible within 3-hour windows, while the high benchmark is exceeded at the 6-hour window for all categories. Taking into account the various behavioural constraints of households this seems more realistic. At the same time, though, benefits are distributed throughout a wider range with both winners and losers among the individual households. 


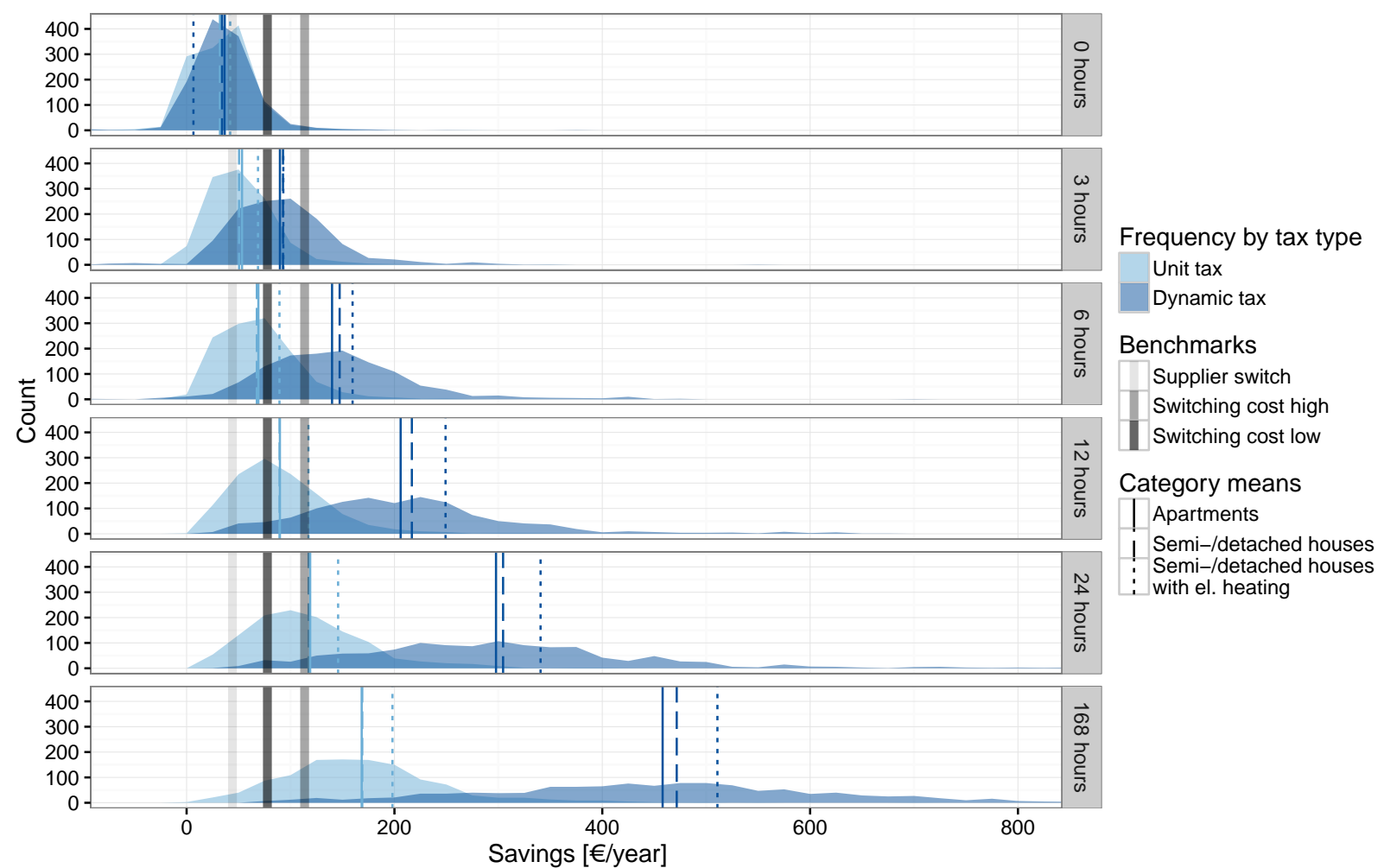

Figure 3: Simulated savings of different load shift simulations with unit and dynamic taxation (total frequency distributions and consumer category means) comparing with switching threshold values

Although the switching cost levels are somewhat hypothetical and very uncertain, they indicate that pure dynamic pricing might be insufficient to convince customers of, firstly, choosing a dynamically priced product and, subsequently, become active in response to the variable prices. Introducing dynamic taxation on the other hand could help to counteract the inertia of consumers and make them switch to dynamic pricing. But also a less intrusive option like the dynamic PSO payment might be helpful. In Figure 4 we show the isolated effect of the dynamic PSO on the distribution of savings (note the shortened horizontal scale). Although effects are smaller than for dynamic taxes, this instrument would exceed the lower switching cost benchmark with 6-hour load shifting windows as well, and could thus be a real alternative to the wide ranging dynamic tax. The option seems particularly relevant with rising levels of the PSO payment to be expected as renewable capacity is further increased. 


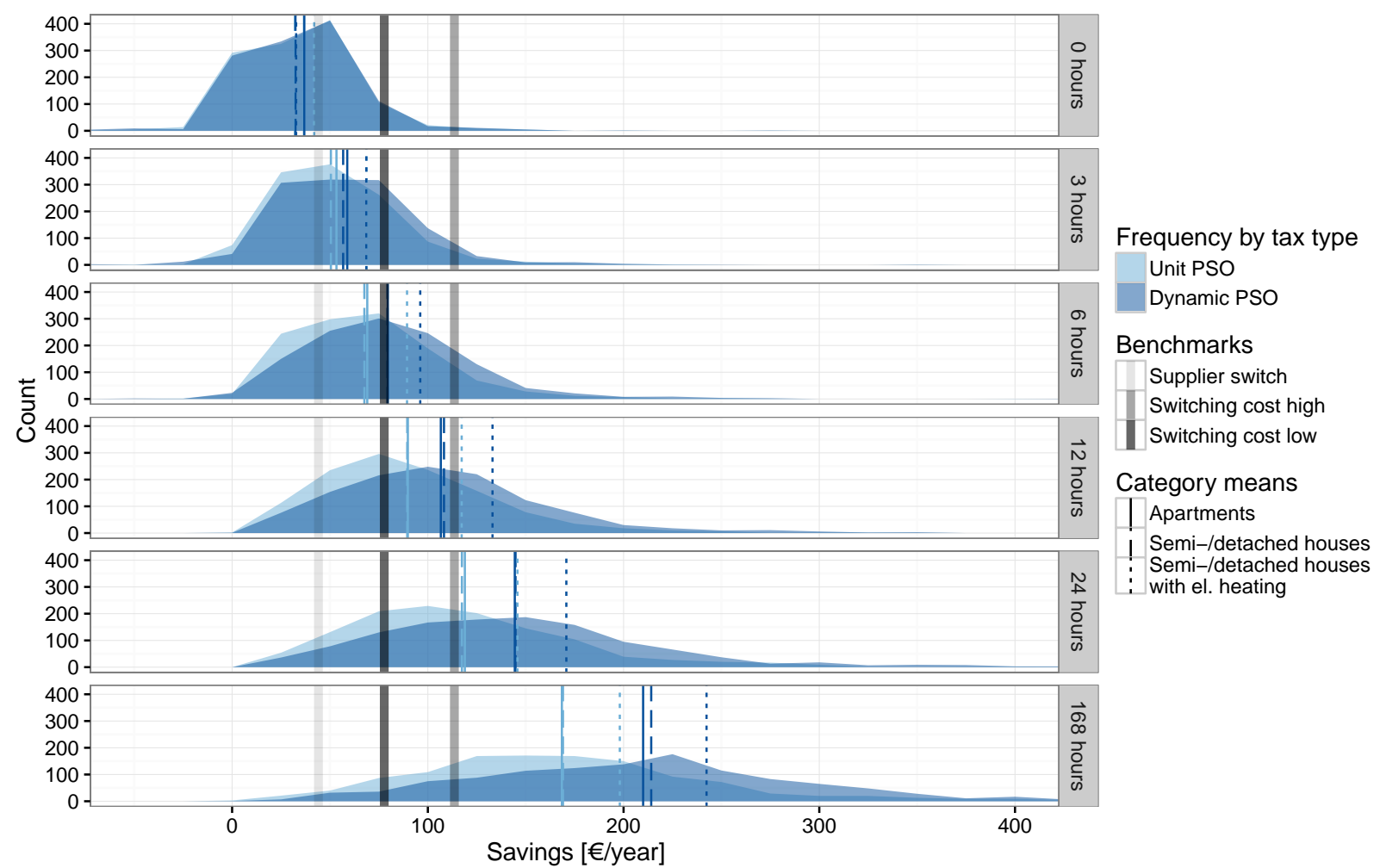

Figure 4: Simulated savings of different load shift simulations with unit and dynamic PSO (total frequency distributions and consumer category means) comparing with switching threshold values

\section{Discussion}

On liberalised electricity retail markets dynamic pricing offers have to compete against other types of retail products. Despite of the high uncertainty in determining a level of benefits that would be sufficient for consumers to switch to dynamic pricing, our simulations show that substantial flexibility will be required from consumers to make savings from dynamic pricing more attractive than other retail market options. Benefits compensating for switching costs suggested by the applied model will be difficult to achieve with simple dynamic pricing. Dynamic taxation, or even just a dynamic PSO payment, has been shown to create an incentive exceeding switching costs at moderate levels of flexibility.

The results are derived for Denmark, but are similarly relevant in other countries with 
high electricity taxes or payments for supported renewable generation. The rationale behind the retail electricity tax system in Denmark to date is primarily to generate an incentive to save energy and so reduce import dependency. This reaches back to the energy crises of the 1970s. ${ }^{45}$ At that time the largest share of electricity was produced from imported fossil fuels; so any unit of electricity saved had an immediate impact on imports. A per-kWh tax thus was well suited to provide the right incentives. Add to that the relatively limited elasticity of electricity demand in the short term, and the tax makes for a reliable and efficient source of government income. With the introduction of more and more low-carbon electricity production largely independent from fuel imports, the energy savings argument might not be as straightforward anymore. In addition timing of savings becomes more crucial in a wind-based system. Thus a dynamic electricity tax seems like an elegant solution to increase the incentive for demand response if a potential is present among consumers. It does, however, introduce a couple of questions as we will discuss in the following.

A fiscal issue of, potentially, more unstable state revenues with dynamic taxes arises from the fact that the tax income in a particular year is subject to uncertainty about both market price and resulting customer responses. As the European Union prescribes a minimum level of electricity taxation, it might be necessary in Member States to account for this in the overall design. Frequent adjustments of the tax rate could stabilise revenues. While technically the problem seems manageable, politically this may pose a substantial issue. ${ }^{46}$ Regarding the PSO levy similar issues in determining future revenues are prevalent in the current system as well: neither production volume, nor market price can be predicted exactly. Currently the levy is adjusted on a quarterly basis; so a frequent adjustment of rates is common practice. If a dynamic tax rate would be kept stable or is adjusted less frequently, we estimate annual variations in the range of $20-30 \%$. By rate adjustments it will be possible to keep revenue variations to a minimum.

From a welfare point of view it is essential to determine whether ad-valorem taxes introduce higher or lower distortions as compared to unit taxes. It is well-established theoretically that, in the case of fully competitive markets, unit and ad-valorem taxation that generate the same revenue are equivalent in terms of distortions. ${ }^{47}$ In oligopolis- 
tic settings ad-valorem taxation may even have the advantage of lower consumer prices than specific taxation raising the same amount of tax revenue. ${ }^{48}$ For electricity such conclusions would only hold on average while in the extreme situations of peak and off-peak consumption revenues will differ between the two techniques of taxation. Eventually, the distortive effect depends on the shape of demand and supply curves, and we cannot at this point conclude which one of the taxation techniques would result in fewer deadweight losses in the Danish retail market. As long as market mechanisms are missing that adequately address the flexibility potential of small-scale actors, a dynamic tax could as well be justified, if flexible household consumers enable the integration of intermittent production from renewable energies and thus provide environmental benefits.

A more political question is the distributional effect: if the total amount of tax income is to remain stable, then benefits for active customers will become a burden for passive customers. Moreover, distributions of results among individual consumers show that some will have better opportunities than others for participating in demand response activities. It would be worth investigating if certain characteristics beyond the categories we apply determine achievable benefits. This could provide the possibility of more targeted measures. Potentially, high income households that do have the resources to invest in, e.g., automation equipment would be likely to benefit more than others. ${ }^{49}$ On the other hand even if low-income customers remain passive, they could benefit from an overall price reduction as a result of demand response from active customers. ${ }^{50}$

The competitiveness of dynamic pricing will change over time, as price patterns develop more in favour of flexible loads with increasing shares of intermittent generation. In the future with even higher shares of production from wind energy we expect to see a significant increase in potential savings if price volatility increases accordingly. The impact of wind on prices in scenarios up to 2035 is noticeable, ${ }^{51}$ and should lead to an increased interest in demand response. Another potential driver of benefits could be the development of dynamic distribution grid charges to reflect local congestions. ${ }^{52}$

In order to prepare for a future situation with a high demand for flexibility, however, it could still be useful to implement additional incentives early on. Our analysis shows that dynamic taxation of electricity certainly is an instrument that adds to the incentive 
of adopting demand response. Savings could increase by a factor three or more for those customers that respond to prices. In combination with a smart meter roll-out and hourly pricing schemes dynamic taxation should be a feasible option to initiate the development of active demand response at household level; especially if substantial adoption of dynamic pricing is to be established before we see noteworthy market price impacts from large-scale renewable generation. If desired, an incentive structure like this could even be gradually phased out again in later years, with variations in energy prices increasing.

\section{CONCLUSIONS}

We have analysed the incentives for household demand response under hourly pricing schemes by calculating potential savings of individual households on their overall electricity bill. The reluctant switching behaviour of household consumers in the Danish retail market indicates that switching supplier or contract is perceived costly. We apply switching costs as a concept to explain the lack of switching, and calculate an estimate using recent observations in Danish retail competition. Accounting for such intangible costs, our results suggest that a combination of smart meter roll-out and the offering of dynamic pricing schemes might be insufficient to convince the average household consumers to switch contracts and become active in response to prices unless they hold a substantial flexibility potential. Distributions of benefits among individual customers, however, show that even if on average the results are only moderately attractive, a dynamic pricing scheme could still have success amongst a smaller group of customers.

Furthermore, our results show that dynamic taxation can help to activate flexible demand on a larger scale. Maintaining the relative effect of hourly price variations after taxes, increases the incentive to respond by a factor three in a Danish setting. Such a change in taxation technique, thus, makes it more likely that customers will switch their supplier and enter into demand-response activities. The issue of varying state revenues could be solved by annual or even quarterly rate adjustments. Distributional and welfare effects remain to be analysed in detail.

It could be an option to introduce an ad-valorem rate only for parts of the electricity 
levies and taxes. Keeping in mind the positive effect of the expected demand response on the integration of renewable production, it may be appropriate to apply dynamic rates only to those elements related to renewable sources (i.e. the so called PSO levy in Denmark). Although effects are smaller, our results suggest that a dynamic PSO payment might be just sufficient to surmount an optimistic estimate of switching costs.

From a policy perspective a gradual approach to encourage dynamic retail pricing seems recommendable. As soon as settlement based on dynamic pricing becomes practically possible in the market, contract offers by suppliers and their respective adoption by consumers should be examined. If adoption lags behind expectation, it should be considered to introduce dynamics within a share of the electricity levies. As of now, the PSO payment seems to be an obvious starting point, but that could change at a later point. As all stakeholders gain experience, further adoption may be induced by introducing the full dynamic tax. During the time such a dynamic system is in place, the market development should be closely monitored. If at some point market prices would provide sufficient signals in support of demand response, commencing a gradual phase-out of the dynamic tax would be possible.

\section{Acknowledgements}

This study is undertaken as joint effort under the iPower and INCAP projects with gratefully acknowledged funding by the Danish Council for Strategic Research.

\section{References}

1. Aidan Tuohy, Ben Kaun, and Robert Entriken. Storage and demand-side options for integrating wind power. Wiley Interdisciplinary Reviews: Energy and Environment, 3(1):93-109, 2014. doi:10.1002/wene.92.

2. Energinet.dk and Dansk Energi. DanGrid: Delrapport Arbejdsgruppe 22, endelig rapport efter høring 12. september 2012 [DanGrid: Sub-report Working Group 22, final report after consultation 12 September 2012]. Technical report, Energinet.dk, Fredericia, Denmark, 2012.

3. Danish Ministry of Climate, Energy and Building. Smart Grid-Strategi - fremtidens intelligente 
energisystem [Smart-Grid Strategy - the future intelligent energy system]. Technical report, Danish Ministry of Climate, Energy and Building, Copenhagen, 2013.

4. Severin Borenstein and Stephen P. Holland. On the efficiency of competitive electricity markets with time-invariant retail prices. RAND Journal of Economics, 36(3):469-493, 2005.

5. Maria Kopsakangas-Savolainen and Rauli Svento. Real-time pricing in the Nordic power markets. Energy Economics, 34(4):1131-1142, 2012. doi:10.1016/j.eneco.2011.10.006.

6. Xian He, Nico Keyaerts, Isabel Azevedo, Leonardo Meeus, Leigh Hancher, and Jean-Michel Glachant. How to engage consumers in demand response: A contract perspective. Utilities Policy, 27:108-122, 2013. doi:10.1016/j.jup.2013.10.001.

7. Frits Møller Andersen, Helge V. Larsen, Lena Kitzing, and Poul Erik Morthorst. Who gains from hourly time-of-use retail prices on electricity? An analysis of consumption profiles for categories of Danish electricity customers. Wiley Interdisciplinary Reviews: Energy and Environment, 3(6):582-593, 2014. doi:10.1002/wene.120.

8. Pil Seok Kwon and Poul Østergaard. Assessment and evaluation of flexible demand in a Danish future energy scenario. Applied Energy, 134:309-320, 2014. doi:10.1016/j.apenergy.2014.08.044.

9. Ea Energianalyse. Kortlægning af potentialet for fleksibelt elforbrug i industri, handel og service [Mapping the potential for flexible electricity consumption in industry, commerce and services]. Report prepared for Energinet.dk and Dansk Energi, Ea Energianalyse, Copenhagen, 2011. URL https://www.energinet.dk/SiteCollectionDocuments/Danske 20 dokumenter/El/ Kort $1 \% \mathrm{C} 3 \% \mathrm{~A} 6 \mathrm{gning} \% 20$ af 20 potentialet $\% 20$ for 20 fleksibelt $\% 20$ elforbrug\% 20 i 20 industri.pdf.

10. Hans Jørgen Jørgensen. Elmåling [Electricity metering], 2014. URL http://www.danskenergi.dk/AndreSider/NetTeknik/Elmaaling.aspx. Accessed: 20-01-2015.

11. Danish Energy Regulatory Authority. Analyse af konkurrencen på detailmarkedet for el [Analysis of competition on the retail market for electricity]. Report, Danish Energy Regulatory Authority, Valby, Denmark, 2012. URL http://energitilsynet.dk/fileadmin/Filer/0_-_Nyt_site/EL/ Nyheder/Analyse_af_detailmarkedet_for_el.pdf.

12. Lena Kitzing, Jonas Katz, Sascha T. Schröder, Poul Erik Morthorst, and Frits Møller Andersen. The residential electricity sector in Denmark: A description of current conditions. Working paper, Department of Management Engineering, Technical University of Denmark, Kgs. Lyngby, 2016. URL 
http://orbit.dtu.dk/files/121099206/The_residential_electricity_sector_in_ Denmark.pdf.

13. S. N. Singh and Jacob Østergaard. Use of demand response in electricity markets: An overview and key issues. In 7th International Conference on the European Energy Market 2010. IEEE, 2010. ISBN 978-1-4244-6838-6. doi:10.1109/EEM.2010.5558728.

14. Inge Røpke and Sophie Nyborg. Energy impacts of the smart home - conflicting visions. In Therese Lindström and Lisa Nilsson, editors, eceee 2011 Summer Study - Energy efficiency first: The foundation of a low-carbon society, pages 1849-1860, Stockholm, 2011. European Council for an Energy Efficient Economy.

15. Malte Jansen, Christoph Richts, Norman Gerhardt, Thorsten Lenck, and Marie-Louise Heddrich. Strommarkt-Flexibilisierung: Hemmnisse und Lösungskonzepte [A flexible electricity market: Barriers and solutions]. Bundesverband Erneuerbare Energie, Berlin, 2015. ISBN 9783920328720. URL http://www.bee-ev.de/fileadmin/Publikationen/Studien/20150216BEE_ Strommarkt_Flexibilisierung.pdf.

16. Ecofys. Der Spotmarktpreis als Index für eine dynamische EEG-Umlage: Vorschlag für eine verbesserte Integration Erneuerbarer Energien durch Flexibilisierung der Nachfrage [The spot market price as an index for a dynamic EEG levy: Proposal for an improved integration of renewable energies by increasing demand flexibility]. Report prepared for Agora Energiewende, Ecofys Germany, Berlin, 2014. URL http: / / www . agora-energiewende.de/fileadmin/downloads/publikationen/ Studien/Dynamische-EEG_Umlage/Agora_RAP_Spotmarktpreis_als_Index_fuer_dyn_ EEG-Umlage_web.pdf.

17. Mikael Togeby, Jesper Werling, János Hethey, Lars Bregnbæk, Anders Kofoed-Wiuff, Hans Henrik Lindboe, Kim Mygind, Jonas Ahmt, Alexandros Filippidis, Peter Meibom, and Poul Erik Morthorst. Bedre integration af vind: Analyse af elpatronloven, treledstariffen for mindre kraftvarmeanlæg, afgifter og andre væsentlige rammebetingelser [Better integration of wind: Analysis of the Electric Boiler Act, the three-part tariff for small cogeneration plants, taxes and other significant framework conditions]. Report prepared by Ea Energianalyse and Risø DTU for the Danish Energy Agency and the Danish Ministry of Taxation, Ea Energianalyse, Copenhagen, 2009.

18. Mikael Togeby, Jesper Werling, and Janos Hethey. Improving taxes, electricity markets and framework conditions to help integrate wind. In Nordic Wind Power Conference 2009, Rønne, 2009.

19. Danish Ministry of Taxation. Redegørelse om muligheder for og virkninger af ændrede afgifter på elektricitet med særlig henblik på bedre integration af vedvarende energi (dynamiske afgifter) 
[Account of possibilities and effects of changed taxes on electricity particularly with regard to better integration of renewable energy (dynamic taxes)]. Technical report, Danish Ministry of Taxation, Copenhagen, 2010.

20. Danish Energy Regulatory Authority. Prisstatistik el-forsyningspligtprodukter [Price statistics supply-obligation products in electricity], 2014. URL

http://energitilsynet.dk/el/priser/prisstatistik-el-forsyningspligt/.

21. Dansk Energi. Forbrugsstatistik [Consumption statistics], 2015.

22. Colin R. Bayliss and Brian J. Hardy. Distribution planning. In Transmission and Distribution Electrical Engineering, chapter 23, pages 867-906. Newnes, Oxford, 3 edition, 2007. ISBN 978-0-7506-6673-2. doi:10.1016/B978-075066673-2/50027-6.

23. Ismail Kasikci. Analysis and Design of Low-Voltage Power Systems: An Engineer's Field Guide. Wiley-VCH, Weinheim, 2004. ISBN 9783527602339. doi:10.1002/352760233X.

24. Adela Conchado and Pedro Linares. The economic impact of demand-response programs on power systems. A survey of the state of the art. In A. Sorokin, S. Rebennack, P.M. Pardalos, N.A. Iliadis, and M.V.F. Pereira, editors, Handbook of Networks in Power Systems, volume 1, pages 281-301. Springer, Berlin, 2012. ISBN 978-3-642-23193-3. doi:10.1007/978-3-642-23193-3_11.

25. Mohamed H. Albadi and Ehab F. El-Saadany. A summary of demand response in electricity markets. Electric Power Systems Research, 78(11):1989-1996, 2008. doi:10.1016/j.epsr.2008.04.002.

26. Goran Strbac. Demand side management: Benefits and challenges. Energy Policy, 36(12):4419-4426, 2008. doi:10.1016/j.enpol.2008.09.030.

27. Ahmad Faruqui and Sanem Sergici. Household response to dynamic pricing of electricity: a survey of 15 experiments. Journal of Regulatory Economics, 38(2):193-225, 2010. doi:10.1007/s11149-010-9127-y.

28. Samuel Gyamfi, Susan Krumdieck, and Tania Urmee. Residential peak electricity demand response-Highlights of some behavioural issues. Renewable and Sustainable Energy Reviews, 25:71-77, 2013. doi:10.1016/j.rser.2013.04.006.

29. Ahmad Faruqui, Dan Harris, and Ryan Hledik. Unlocking the $€ 53$ billion savings from smart meters in the EU: How increasing the adoption of dynamic tariffs could make or break the EU's smart grid investment. Energy Policy, 38(10):6222-6231, 2010. doi:10.1016/j.enpol.2010.06.010.

30. NordREG. Nordic Market report 2014: Development in the Nordic Electricity Market. Report 4/2014, NordREG Nordic Energy Regulators, Eskilstuna, 2014. 
31. NordREG. Nordic Market report 2012: Development in the Nordic Electricity Market. Report 3/2012, NordREG Nordic Energy Regulators, Helsinki, 2012.

32. Mads Lyndrup. Kunderne og elprisen i 2015 [Customers and the electricity price in 2015]. Presentation, Danish Energy Regulatory Authority, Valby, 2016. URL

http://energitilsynet.dk/fileadmin/Filer/0_-_Nyt_site/Forside/2016_-Energiforum/160530_-_ML_-_FINAL_FINAL_elprisundersoegelse.pdf.

33. Philipp Pfeifroth, Florian Samweber, Thomas Gobmaier, and Markus Rüger. Funktionaler Stromspeicher mit Haushaltskühlgeräten [Functional electricity storage with domestic cooling appliances]. BWK, 64(12):29-33, 2012.

34. Daniel Torstensson and Fredrik Wallin. Potential and barriers for demand response at household customers. Energy Procedia, 75:1189-1196, 2015. doi:10.1016/j.egypro.2015.07.570.

35. Sarah J. Darby and Eoghan McKenna. Social implications of residential demand response in cool temperate climates. Energy Policy, 49:759-769, 2012. doi:10.1016/j.enpol.2012.07.026.

36. Guido Pepermans. Valuing smart meters. Energy Economics, 45:280-294, 2014. doi:10.1016/j.eneco.2014.07.011.

37. Simon Kaufmann, Karoline Künzel, and Moritz Loock. Customer value of smart metering: Explorative evidence from a choice-based conjoint study in switzerland. Energy Policy, 53:229-239, 2013. doi:10.1016/j.enpol.2012.10.072.

38. Elisabeth Dütschke and Alexandra-Gwyn Paetz. Dynamic electricity pricing-Which programs do consumers prefer? Energy Policy, 59:226-234, 2013. doi:10.1016/j.enpol.2013.03.025.

39. Michael A. Jones, David L. Mothersbaugh, and Sharon E. Beatty. Why customers stay: measuring the underlying dimensions of services switching costs and managing their differential strategic outcomes. Journal of Business Research, 55(6):441-450, 2002. doi:10.1016/S0148-2963(00)00168-5.

40. Oz Shy. A quick-and-easy method for estimating switching costs. International Journal of Industrial Organization, 20(1):71-87, 2002. doi:10.1016/S0167-7187(00)00076-X.

41. Christophe Defeuilley and Matthieu Mollard. The dynamic of competition in presence of switching costs. The case of British Gas (1997-2007). Working paper, GIS LARSEN, 2008. URL

http://www.gis-larsen.org/Pdf/LARSEN_WP_17VA.pdf.

42. Jackie Krafft and Evens Salies. The diffusion of ADSL and costs of switching Internet providers in the broadband industry: Evidence from the French case. Research Policy, 37(4):706-719, 2008. doi:10.1016/j.respol.2008.01.007. 
43. Fredrik Carlsson and Åsa Löfgren. Airline choice, switching costs and frequent flyer programmes. Applied Economics, 38(13):1469-1475, 2006. doi:10.1080/00036840500419608.

44. Energinet.dk. Detailmarkedsrapport nr. 2 [Retail market report no. 2]. Dok. 15/12493-5, Energinet.dk, Fredericia, 2016. URL http://www. energinet.dk/SiteCollectionDocuments/ Danskedokumenter/E1/2016-01Detailmarkedsrapportnr.2.pdf.

45. Mogens Moe. Miljøret [Environmental law]. Thomson, Copenhagen, 6 edition, 2007. ISBN 9788761919304 .

46. Kim Østrup. Why there is no market for the smart grid today. In Rasmus Ulslev Pedersen and Ivan Häuser, editors, Essays on the smart grid, pages 13-20. DJØF Publishing, Copenhagen, 2013.

47. John A. Kay and Michael J. Keen. How should commodities be taxed? European Economic Review, 23: 339-358, 1983. doi:10.1016/0014-2921(83)90037-5.

48. Michael J. Keen. The balance between specific and ad valorem taxation. Fiscal Studies, 19(1):1-37, 1998. doi:10.1111/j.1475-5890.1998.tb00274.x.

49. Barbara R. Alexander. Dynamic pricing? Not so fast! A residential consumer perspective. The Electricity Journal, 23(6):39 - 49, 2010. doi:10.1016/j.tej.2010.05.014.

50. Severin Borenstein. The long-run efficiency of real-time electricity pricing. The Energy Journal, 26(3): 93-116, 2005. doi:10.5547/ISSN0195-6574-EJ-Vol26-No3-5.

51. Karsten Capion and Peter Meibom. Elprisscenarier 2020-2035 [Electricity price scenarios 2020-2035]. Analyse 20, Dansk Energi, Frederiksberg, 2016. URL http://www . danskenergi.dk/\$ \im\$/ media/DE_MJE/Analyser/Analyse20-Elprisscenarier2020-2035.ashx.

52. Niamh O'Connell, Qiuwei Wu, Jacob Østergaard, Arne Hejde Nielsen, Seung Tae Cha, and Yi Ding. Day-ahead tariffs for the alleviation of distribution grid congestion from electric vehicles. Electric Power Systems Research, 92:106-114, 2012. doi:10.1016/j.epsr.2012.05.018. 